\title{
A comparison of the levels of satisfaction with the medical services provided by primary healthcare centers in selected communes in Lubelskie Voivodeship
}

\begin{abstract}
Introduction. Family medicine remains the primary type of medical services in Poland and it is supposed to treat both individual patients and the society as a whole. Due to the growing commercialization of the health service, most primary healthcare centers have transformed into non-public healthcare facilities. The public ones (called SPZOZ in Polish) account only for a small fraction of the whole number of primary healthcare facilities. The quality of medical services provided by such facilities, as patients see it, remains one of the key elements determining the development of family medicine centers.

Aim. The aim of this paper was to assess patient satisfaction levels regarding the healthcare services they received in two primary healthcare institutions, both of the NZOZ and SPZOZ type, in a small town located close to Lublin.

Material and methods. An anonymous survey was filled out by 30 patients of both a public and non-public healthcare center located in Niemce (Niemce Commune, Lublin District). The quality of services was assessed using an original questionnaire in the form of a poll.

Results. The results obtained indicate a clear relationship between one's trust to the physician, diagnosis accuracy and visiting the particular center again, in order to continue the treatment. For older subjects, it was nurses' kindness and politeness that was the most important. The elderly appreciated the kindness and politeness of the nurses in particular. No significant differences were found between the institutions in respect of the overall perception of satisfaction with services. In terms of infrastructure assessment, the majority of positive feedback was provided for NZOZ.

Conclusions. The findings above suggest that it is essential to conduct surveys on a regular basis, in order to check patients' assessment of the service quality in various institutons.
\end{abstract}

Keywords: quality, satisfaction, public primary healthcare, non-public primary healthcare.

DOI: $10.1515 /$ pjph-2016-0002

\section{INTRODUCTION}

Primary healthcare has huge influence over the health of both the individual and the society as a whole. Recent advancements in technology and medical knowledge, supported by a good management strategy, can produce very favorable outcomes in relation to public health. An investigation of the quality of the services provided, looked at through the lens of patients' needs might prove to be a crucial factor shaping the quality of healthcare services and the way they operate. Given the above, it is vital that patients' feedback be obtained about the services provided by primary healthcare centers, as it will make it possible to modify the relevant strategies and plan the future operations of such centers and other components of the healthcare system. In view of the volatile demographic and economic trends apparent in small communities, a well-designed system for the assessment of patient satisfaction with the provided services is of paramount importance for the enhancement of standards and the quality of services. The assessment of the quality of the provided medical services should be considered one of the major determinants of changes in primary healthcare center (PHC) management strategies.

The authors of the study looked to compare patients' feedback concerning the quality of healthcare service provided by two centers, SPOZ and NZOZ, operating in small towns in the Lubelskie Province.

\section{AIM}

The aim of this paper was to assess patient satisfaction levels regarding the healthcare services they received in two primary healthcare institutions, both of the NZOZ and SPZOZ type, in a small town located close to Lublin.

\footnotetext{
${ }^{1}$ Department of Hygiene, Medical University of Lublin, Poland

${ }^{2}{ }^{\text {It }}$ Department of Radiology, Medical University of Lublin, Poland

${ }^{3}$ Department of Public Health, Medical University of Lublin, Poland

${ }^{4}$ Ergonomics and Occupational Hygiene Department, Technical University of Lublin, Poland

${ }^{5}$ Department of Prevention of Digestive System Diseases, Nursing Institute, Jan Kochanowski University of Kielce, Poland

${ }^{6}$ Theory and Application of Text Chair, Faculty of Social Science, The John Paul II Catholic University of Lublin, Poland

${ }^{7}$ Jordan Family Health Center, Salt Lake City, USA
} 


\section{MATERIAL AND METHODS}

Patients attending two primary healthcare institutions in Niemce, a town in the Niemce Commune, Lublin District were subject of the study. The study was anonymous and voluntary.

An original questionnaire in the form of a survey was used. It included questions concerning respondents opinions on the medical services provided, medical staff, social conditions, infrastructure and the way the facility is managed. The research tool used in this study was designed in line with the rules and guidelines for developing surveys for collecting data during social studies [1]. Instructions on how to complete the questionnaire were provided on the first page of the survey. Respondents were asked to tick the answer they found appropriate, or, in some questions, provde their own observations. The whole questionnaire comprised a demographics section including the patients' individual perception of their financial situation, and 27 questions connected with their opinion about the staff (two questions), diagnostics and treatment (ten questions), visits to the surgery (four questions), involvement of their relatives, social conditions, the availability of services at night, prevention programs offered by the center, and the changes in the center and the way the facility is managed (one question each). In two open-ended questions respondents could provide feedback on what they believed were the strongest and the weakest points of the facility. In response to some questions the study used a Likert scale, which provided information on the level of acceptance or assessment of the issues in question. No patient had any problems with providing answers to the questions.

The obtained data were analysed using descriptive statistics methods. The data, patient profiles and answers were entered into a table. The grading of negative responses was reversed, which means that, in respect of all questions, higher totals indicated a higher level of satisfaction.

\section{RESULTS}

The authors of the study divided the respondents $(n=60)$ into two groups of 30 persons each from each PHC center, i.e. Group 1 from the Independent Public Healthcare Institution (SPZOZ) and Group 2 from the Non-Public Healthcare Institution (NZOZ). Regarding the work status four age brackets were identified within each Group, i.e. Bracket 1 - below 18 (pre-working age), Bracket 2-18 to 44 (mobile working age), Bracket 3-45 to 64 (non-mobile working age), and Bracket 4-65 or more (post-working age).

Group 1 comprised mostly female participants - it included 20 women and 10 men (accounting for $66.67 \%$ and $33.33 \%$ respectively). The average age of respondents was 40.2 years (15-66). This group included respondents of all age ranges, with Bracket 2 respondents as the most numerous (56.67\%). Most respondents (29 people or $96.67 \%$ ) were rural residents, of which 20 were female and 9 male. One person (male) was a city resident. The most numerous group were respondents with secondary education $(66.68 \%)$. The second most numerous group was people with higher education (26.66\%), while respondents with primary education formed the smallest group (approx. 6.66\%). The largest group in Bracket 2 was represented by people with secondary education. This Bracket, as the only one, included respondents with higher education. All respondents included in Bracket 3 had secondary educa- tion. Among people aged 65 or more (Bracket 4) 50\% had primary education and the other $50 \%$ had completed secondary education. In terms of employment, $60 \%$ of all respondents were old-age pensioners with some disabilities. Working persons comprised the second most numerous group (20\%) among those surveyed. Non-working individuals (students and the unemployed) made up approx. $16.66 \%$ of all the surveyed people. One person provided no information about their professional activity. Bracket 2 included most unemployed/nonworking persons (5) out of all age groups. That Bracket also included the greatest number of professionally active respondents (40\%). Women dominated among both professionally inactive and active persons, accounting for 4 and 9 respondents, respectively. Old-age/disability pensioners dominated Bracket 3 (3 women, 1 man) and comprised one group in terms of professional activity among those aged $65+$. Respondents assessed their financial situation using a five-point scale, ranging from very bad to bad, satisfactory, good and very good. Half the respondents (50\%) assessed their situation as good, approx. $40 \%$ as satisfactory, and $6.66 \%$ as bad. None of the respondents chose very bad as their answer. One person assessed their situation as very good. In Bracket 1 , one respondent assessed their situation as good. This answer was shared by as many as 12 respondents in the most-numerous Bracket 2. Bracket 3 was dominated with respondents considering their situation as satisfactory $(23.3 \%)$. The most-popular answers in the $65+$ group were satisfactory and good. Most $(80 \%)$ of the Group 1 respondents used medical services no more than a few times a year.. Approx. 16\% of respondents did so several times a month. None of the persons asked to complete the survey visited their GP once a week. Only five respondents (one from Bracket 2 and one from Bracket 4, and three from Bracket 3), exclusively female, declared that they had visited their local clinic several times a month, while men in all Brackets used medical services only a few times a year. The most-numerous group among those declaring several visits a year were women from Bracket 2-11 individuals.

Group 2, similarly to Group 1, comprised mainly women (23, accounting for $76.66 \%)$, while men (7) represented $23.34 \%$ of the total. With the youngest person aged 20 and the oldest aged 71, the average age of respondents, 35.5 years, was lower than in Group 1. In contrast to Group 1, none of the respondents was classified under Bracket 1. Similarly to Group 1, Bracket 2 covered the greatest number of people, with women clearly predominating $(80 \%)$. Brackets 3 and 4 comprised of women only (100\%). All male respondents were in the 18-44 age group. Rural and urban residents represented, respectively, $99.33 \%$ and $6.67 \%$ of respondents. Most Group 1 members reported to hold a secondary education degree - it applied to some $60 \%$ of the total (mainly in Brackets 2 and 3 , predominantly women). Individuals holding a higher education degree comprised the second largest group - they accounted for $30 \%$ of the respondents (Bracket 2). The smallest group, representing $10 \%$, were respondents with primary education (only women from Brackets 2 and 3). In terms of employment, proportions among Group 2 respondents were similar as in the case of SPZOZ patients (Group 1). With 56.66\%, old-age/disability pensioners represented a substantial majority. Working individuals were the second-largest population in Group 2. There were also non-working individuals and students - these group accounted for $13.34 \%$ of the total. Two individuals provided no answer to the question concerning 
their professional activity. More than a half of the Group 2 respondents (53.34\%) assessed their financial situation as good. Nearly one third considered it satisfactory. Representing $13.33 \%$, a marked proportion of respondents evaluated their situation as very good. One person chose bad to describe their situation. None of the respondents chose very bad as their answer. In Bracket 2, the majority of respondents, i.e. as many as 14 respondents (10 female and 4 male), assessed their financial situation as good. Respondents who considered their situation satisfactory also dominated the 14-44 age group, accounting for $20 \%$, compared to other brackets. The largest group, with 22 individuals ( $73.33 \%$ of the total) reported using healthcare services (NZOZ) no more than a few times a year. Seven persons $(23.34 \%)$ visited medical facilities several times a month. One respondent did so at least once a week. All men (Bracket 2) declared visiting a clinic a few times a year. The most-numerous group among those declaring several visits a year were women from Bracket 2 (10).

The authors assessed the level of correlations between the feedback from the surveyed patients on selected issues associated with the quality of services provided in both primary healthcare centers in Niemce using Spearman's rank correlation coefficient. In order to determine the direction and level of the correlations between the variables (questions), the study adopted values ranging from -1 to 1 , where the closer the number to 1 (or -1 ), the stronger the correlation (Table 1) [2].

TABLE 1. The assessment of selected monotonic trends between the analysed variables and Spearman rank correlation coefficients.

\begin{tabular}{|c|c|}
\hline Analysed variables & $\begin{array}{l}\text { Spearman's rank } \\
\text { correlation } \\
\text { coefficient }\end{array}$ \\
\hline $\begin{array}{l}\text { Confidence in the accuracy of diagnoses and treatment } \\
\text { methods (Question 17) and the continued use of GP } \\
\text { services in a given primary healthcare unit (Question 23). }\end{array}$ & $\mathrm{r}=0.32$ \\
\hline $\begin{array}{l}\text { The continued use of GP services in a given primary } \\
\text { healthcare unit (Question 23) and the fact of medical } \\
\text { staff's ignoring information about any discomforts } \\
\text { or disturbing symptoms following medicine } \\
\text { administration (Question 13). }\end{array}$ & $\mathrm{r}=-0.48$ \\
\hline $\begin{array}{l}\text { The level of kindness, care, compassion and interest } \\
\text { showed by the nurses in a primary healthcare unit } \\
\text { (Question 2) and the age of respondents. }\end{array}$ & $\mathrm{r}=0.61$ \\
\hline $\begin{array}{l}\text { Confidence in the accuracy of diagnoses and treatment } \\
\text { methods (Question 17) and the continued use of GP } \\
\text { services in a given primary healthcare unit (Question 23). }\end{array}$ & $\mathrm{r}=0.32$ \\
\hline $\begin{array}{l}\text { The level of kindness, care, compassion and inter- } \\
\text { est showed by the nurses in a primary healthcare unit } \\
\text { (Question 2) and the level of kindness, care, compassion } \\
\text { and interest showed by the doctor (Question 3). }\end{array}$ & $\mathrm{r}=0.69$ \\
\hline $\begin{array}{l}\text { The provision of information to the patient about their } \\
\text { rights and responsibilities (Question 5) and the under- } \\
\text { standing of such information (Question 6). }\end{array}$ & $\mathrm{r}=0.91$ \\
\hline $\begin{array}{l}\text { Embarrassing conversations about the patient held } \\
\text { between medical personnel in the patient's presence } \\
\text { (Question 14) and the continued use of the GP facility } \\
\text { (Question 23). }\end{array}$ & $\mathrm{r}=-0.8$ \\
\hline $\begin{array}{l}\text { The weakest point of a facility according to the patient } \\
\text { (respondents could provide their own answer) (Question } \\
\text { 21a-open-ended) and the reasons for extended } \\
\text { appointment waiting times (Question } 4 \text { ). }\end{array}$ & $\mathrm{r}=-0.7$ \\
\hline $\begin{array}{l}\text { The weakest point of a facility according to the patient } \\
\text { (respondents could provide their own answer) (Question } \\
21 \mathrm{a}-\text { open-ended) and difficulties in obtaining informa- } \\
\text { tion about the progress of treatment (Question 10). }\end{array}$ & $\mathrm{r}=-0.82$ \\
\hline
\end{tabular}

Significance for $\mathrm{p}<0.05$
The patients' age or sex had no significant influence over the average perception of the quality of the services provided by the centers. Respondents in both groups were generally satisfied with their GPs. Respondents also reported a generally high level of satisfaction with the overall level of care in both centers.

The evaluation of monotonic trends between the analysed variables showed a positive Spearman rank correlation between the frequency of visits to the healthcare center providing family medicine services, and the age of the respondent $(\mathrm{r}=0.43$ for $\mathrm{p}<0.05$ ). These findings indicate that the frequency of visits to the healthcare center increases to about once a week as the respondents' grow older (persons included in Brackets 3 and 4, with predominantly elderly populations). Also, the respondents who were confident about the diagnosis accuracy (Question 17) were much more likely to visit the same health facility again (Question 23) than those who had less confidence ( $r=0.32$ ).

In case patients' comments about any discomfort or disturbing symptoms after taking medication were ignored (Question 13), these individuals were less likely to visit a particular healthcare facility again (Question 23) than those whose comments were paid attention to (Table 1). Patients included in Brackets 3 and 4, unlike representatives of other age groups (a statistically significant and strong correlation, with $\mathrm{r}=0.61$ for $\mathrm{p}<0.05$ ) were most likely to deem kindness, care, compassion and interest showed by nurses an important feature. In both healthcare centers, the respondents who ranked high the kindness, care, compassion and interest showed by nurses, proved much more likely to rank these parameters highly in GPs than those who ranked nurses lower $(r=0.69)$. The vast majority of respondents who received information about their rights and responsibilities considered the information comprehensible and exhaustive $(\mathrm{r}=0.91)$. The results obtained $(\mathrm{r}=-0.8)$ show that a considerable majority of persons who have had negative experiences related to embarrassing conversations between medical staff tends to choose that clinic as their future family medicine service provider, as compared to respondents who have had no such experiences. It was also demonstrated that the respondents who have had to wait longer for their appointment as a result of the lack of interest on the part of medical staff, or other reasons, are much more likely to assess that medical facility negatively $(\mathrm{r}=-0.7)$. A similar trend was observed during the analysis of Question 21a variables (the worst element in a clinic - an open-ended question) and any difficulties in obtaining information on the progress in treatment (Question 10) $(\mathrm{r}=-0.82)$. This shows that patients who have had problems with obtaining information about the progress in their treatment are much more likely to report any downsides of that clinic than other respondents who have had no such experiences.

\section{DISCUSSION}

Primary healthcare facilties can be either public or private and the two types often operate side by side. Patients are free to choose any facility they want, which means that the two types of facilities compete for patients, as they operate on a basic principle - the more patients there are, the more money they receive. In this context, the level of satisfaction with the received services is of special importance for implementing the expected changes in the operational policies of $\mathrm{PHC}$ and addressing the needs of patients in everyday practice. By now, 
only a few authors have touched upon the problem of two healthcare units (with different forms of ownership) operating in one small town.So far, there have been few studies on this problem that had explored the functioning two healthcare facilities with different forms of ownership and operating in the same town, especially a small one.

The findings of this study show that patients in the Niemce Commune are generally very satisfied with the quality of the services provided, with the non-public healthcare center holding a narrow lead in terms of positive feedback. Kulczycka et.al. [3] analyzed the feedback of patients attending both public and private health centers operating in one district of Lublin and they drew similar conclusions.. Ever since healthcare units have become privately-owned, the standards of patient care improved. There is also a need to acknowledge the needs of healthcare recipients in the plans for the achievement of their objectives by PHC units [3,4]. This fact could explain the above-mentioned trend. In this study, the high level of satisfaction with the rendered primary healthcare services was found especially in relation to the assessment of the work performance and relations between the medical staff, both nurses and doctors. A research study based on surveys handed out to over a thousand patients attending one of the twelve healthcare centers in Gdańsk and Sopot chosen at random provided similar conclusions - patients had rather positive opinions about doctors and nurses.. The proportion of patients who assessed different aspects of care provided by nurses and doctors as very good or good ranged from $78 \%$ to $97.8 \%$ [5]. A similarly high number of positive opinions was recorded in Lublin - 59$69 \%$ [3], Giżycko - 89-90\% [6,7], Warsaw - 73.7\% [5] and Radzyń Podlaski - approx.70\% [8]. Marcinowicz et.al. [9] had the following findings - only 4.7 assessed patient-nurse relations as negative, while in Bydgoszcz it was $1.78 \%$ [10]. It appears that most patients are dissatisfied because the medical staff showen little interest in them, there were indifferent and had a routine approach $[10,11]$. This proves how important are the relations between the staff and patients. Plus to that, these relationships are important for keeping the care standards high. Similar high levels of patient satisfaction were reflected in feedback obtained during visits in both primary healthcare centers in Niemce. Patients rarely reported any problems concerning obtaining information about the process of treatment, their rights, diagnostic procedures, etc. Also, the information was provided in a clear and understandable way. Patients were also satisfied with the availability and clarity of information $[6-8,10]$. Other factors that influence the choice of the facilty and quality perception include the overall infrastructure, the appearance, the social conditions at the care facility. Patients feel comfortable in well-organized and friendly clinics that meet their needs, evoke positive feelings and reduce uncertainty and anxiety. In most cases, private facilities provide better equipment and infrastructure, which results in better feedback from patients. The majority of positive feedback about this issue, as found in the analysed literature, is received by non-public PHC centers, as compared to the public ones $[8,12]$. A similar trend was observed during the survey for this study. In Niemce, the volume of positive feedback was higher for NZOZ than for SPZOZ. To some extent, this discrepancy can be explained by the fact that the SPZOZs were undergoing modernizationduring the study. There are high odds that after the modernization is finished, the difference would vanish. One of the main aspects of satisfaction with, and, consequent- ly, the quality of medical services, that needs to be measured, while accounting for any financial, organisational, cultural and emotional barriers, is their availability, understood as the accessibility of healthcare for the patient. When it comes to the issue of healthcare availability, such factors as healthcare accessibility and the convenience of such access should be taken into consideration [13]. Healthcare ability, especially in relation to PHC, is the key indicator for the effectiveness of the system as a whole. The findings of this study in the Niemce Commune show that respondents from both healthcare centers provided a similar, negative feedback on the availability of family medicine services outside the business hours of these centers. Bojar et al. had similar findings [14] for patients living in rural areas outside Lublin but using PHC services in the city. In most studies, big city residents were more likely to have favorable opinions regarding the overall availability of PHC services $[5,7,10,12,15-20]$. One study looking at various facilities in Lublin, Stalowa Wola, Kielce and Krosno revealed that only a half the respondents assessed the availability of PHC services as good. The issue of availability also received poorer feedback in studies conducted in other district towns, such as Giżycko [6,7] and Sepólno Krajeńskie [10]. Residents of big cities were more likely to have favorable opinions of medical facilities, since these setvices are operating longer and they are open at night or during bank holidays, which is not so obvious in small towns. Primary healthcare organized this way provides patients with actual health security. This disparity in the access to healthcare between the residents of towns and cities is, i.a., due to the lack of sufficient medical staff in rural areas and funds for securing such professionals. This means, there is a need for changes of healthcare management policy in the regional level. There are various studies, conducted both in Poland and in other places, suggesting that patients are usually dissatisfied with the medical service they receive, since they have limited access to specialist advice [11,19,2123]. This was suggested by study participants in open-ended quesitons. This problem pertained to small town residents in particular [19]. The obtained findings confirm the existence of the above-mentioned issue among the patients of healthcare centers in Niemce. Changes in the organisation of work and healthcare management, introduced as a result of reforms, are the most rapid of all medical fields. Along the changing operational conditions and provided services, there has been a gradual increase in patient satisfaction levels [6,7]. Surveys conducted by Marcinowicz et al.[6] in 1998, 2002 and 2006 show an increase in the number of patients satisfied with PHC services from $81.2 \%$ (in 1998) to $86.4 \%$ (in 2006). As Bojar et al found out in their 2001 study [14], some $70.14 \%$ of the patients attending an outpatient clinic in Lublin have not noticed any links between healthcare system reforms and service quality improvement.

Our findings, as well as the findings quoted in the literature below confirm that patients are overall satisfied with the provided services. The comparison of these results with those available in the literature on the subject is doomed to encounter problems associated not only with the satisfaction assessment methods used by different authors in relation to the quality of healthcare services, and especially different survey models, but also the locations covered by such surveys. Improving the quality of services is one of the key aims that every healthcare facility looks to fulfill, which is reflected by a numerous documents concerning the future development of 
Poland and the EU [24]. The process of quality improvement requires the preparation, implementation and regular monitoring of healthcare services. Consequently, it is important to revise the to-date approach to meet the needs and expectations of patients across different areas. Family medicine in Poland continues to face new challenges and the further advancement of primary healthcare and the whole healthcare system relies on the relevant management policies' rising to such challenges [25].

So far, there have been numerous studies looking at the quality of primary healthcare services, both in Poland and worldwide, looking at residents of large cities and cities with district rights The aspects touched upon in this paper and surveyed at the commune level, as the smallest administrative unit, have no proper equivalent in the available literature. In communes and towns, especially where primary healthcare is frequently the only element of the healthcare system available, the assessment of the quality of medical services deserves sufficient consideration in the development of healthcare facility management policies. The presented findings offer valuable insights for administrators of PHC facilities and can encourage further research into this area.

\section{REFERENCES}

1. Gruszczyński L. Kwestionariusze w socjologii. Budowa narzędzi do badań surveyowych. Wyd. 4 zmienione. Katowice; 2003.

2. Watała W. Biostatystyka - wykorzystanie metod statystycznych w pracy badawczej w naukach biomedycznych. Alfa-medica Press; 2002

3. Kulczycka K, Stychno E, Wdowiak L. Publiczne i niepubliczne zakłady podstawowej opieki zdrowotnej w opinii pacjentów. Ann UMSC sectio D. 2004;LIX(Suppl. 14):262-6.

4. Windak A, Panasiuk L. Medycyna rodzinna w systemie ochrony zdrowia. Zdr Publ. 2005;115(3):267-73.

5. Miller M, Supranowicz P, Gębska-Kuczerowska A, et al. Ocena poziomu satysfakcji pacjentów jako element jakości pracy podstawowej opieki zdrowotnej. Pol Merk Lek. 2007;XXIII(137):367-70.

6. Marcinowicz L, Konstantynowicz J, Chlabicz S. The patient's view of the acceptability of the primary care in Poland. In J Quality Health Care. 2008;20(4):277-83.

7. Marcinowicz L, Chlabicz S. Improvement in the accessibility and organization of services of family physicians in a small town in Poland: a comparison of patient opinions between 1998 and 2002. Adv Med Scie. 2006;52:226-31.

8. Steć A, Wołyniak M, Wdowiak L. Satysfakcja pacjentów z usług świadczonych przez wybrane niepubliczne zakłady opieki zdrowotnej. Probl Hig Epidemiol. 2007;88(3):272-6.

9. Marcinowicz L, Górska A, Chlabicz S. Przyczyny niezadowolenia pacjentów z opieki lekarza rodzinnego w świetle badań ankietowych analiza odpowiedzi na pytania otwarte. Prz Lek. 2007;64(9):559-62.

10. Łukomska A, Rość D, Faleńczyk K. Satisfaction of patients treated by a family doctor. Fam Med Prim Care Rev. 2008;10(2):167-72.

11. Marcinowicz L, Grębowski R. Ocena opieki lekarza rodzinnego w świetle badań jakościowych: poszukiwanie komponentów zadowolenia i niezadowolenia pacjentów. Fam Med Prim Care Rev. 2008;10(2):173-9.

12. Nowakowski B. Assurances sociales. In: M. Kacprzak. L'hygiene publique en Pologne. Warszawa: "Siła"; 1933. p. 208-22.

13. Borek-Wojciechowska R, Kłokow S. Dostępność świadczeń podstawowej opieki zdrowotnej jako jeden z aspektów jakości opieki. Zdr Publ. 2007;117(3):381-5.

14. Bojar I, Ostrowski T, Wdowiak L. Satysfakcja pacjentów z usług podstawowej opieki zdrowotnej w mieście Lublin. Ann UMCS sectio D. 2004;LIX(Suppl. 14):185-9.

15. Łukomska A. Dostępność świadczeń lekarza rodzinnego w ocenie pacjentów. Fam Med Prim Care Rev. 2008;10(2):162-6.

16. Kulczycka K, Stychno E, Wdowiak L. Satysfakcja pacjentów korzystających $\mathrm{z}$ usług podstawowej opieki zdrowotnej po przeprowadzonej reformie ochrony zdrowia. Ann UMSC sectio D. 2004;LIX(Suppl. 14):267-70

17. Pietryka-Michałowska E, Wdowiak L, Szymańska J. Lekarz pierwszego kontaktu w opinii pacjentów. Cz. II Oczekiwania pacjentów. Zdr Publ. 2006;116(2):250-4.

18. Bojar I, Wdowiak L, Osrtowski T, et al. Dostępność poradni POZ w Lublinie w opinii pacjentów. Zdr Publ. 2004;114(3):304-6.

19. Pietryka-Michałowska E, Wdowiak L, Szymańska J. Lekarz pierwszego kontaktu w opinii pacjentów. Cz. II Oczekiwania pacjentów. Zdr Publ. 2006;116(2):250-4.

20. Pyra K, Raganowski P, Jabłońska J, et al. Ogólna ocena usług medycznych oferowanych przez Zakłady Podstawowej Opieki Zdrowotnej w opinii pacjentów. Ann UMCS sectio D. 2007;62(Suppl. 18):275-9.

21. Misiuna M. Zmiany ocen opieki zdrowotnej i ich społeczne zróżnicowanie. Zdr Publ. 2005;115(3):296-302.

22. Glynn LG, Byrne M, Newell J, et al. the effect of health status on patients' satisfaction with out-of-hours care provided by a family doctor co-operative. Fam Pract. 2004;21:677-79.

23. Montaglione CJ. The physician-patient relationship: comerstone of patient trust, satisfaction and lojalisty. Manag Care Quart. 1999;7(3):5-22.

24. [http://www.mz.gov.pl/]

25. Coulter A. The Autonomous Patient. Ending paternalism in medical care. London: The Nuffield Trust; 2003. p. 106-21.

\section{Corresponding author}

Daria Przybylska

Department of Hygiene, Medical University of Lublin

11 Radziwiłłowska Str.,20-400 Lublin

tel. +48 81 448-61-30

E-mail: dr.przybylska@gmail.com 